\title{
The Walls of Jericho: An Alternative Interpretation
}

\section{Citation}

Bar-Yosef, 0. 1986. The Walls of Jericho: An Alternative Interpretation. Current Anthropology 27, no. 2: 157-162.

\section{Published Version}

doi:10.1086/203413

\section{Permanent link}

http://nrs.harvard.edu/urn-3:HUL.InstRepos:12211567

\section{Terms of Use}

This article was downloaded from Harvard University's DASH repository, and is made available under the terms and conditions applicable to Other Posted Material, as set forth at http:// nrs.harvard.edu/urn-3:HUL.InstRepos:dash.current.terms-of-use\#LAA

\section{Share Your Story}

The Harvard community has made this article openly available.

Please share how this access benefits you. Submit a story.

\section{Accessibility}


REPORTS

\section{The Walls of Jericho: An Alternative Interpretation $^{1}$}

\author{
by O. BAR-YOSEF \\ Institute of Archaeology, Hebrew University, Jerusalem \\ 91905 , Israel. 30 vi 85
}

"The walls of Jericho" immediately remind us of the biblical story describing the conquest of this ancient town by Joshua and the invading Israelite army. Like the Homeric epic about the destruction of Troy, which motivated H. Schliemann to conduct one of the first excavations in the Near East, so the tale of Jericho has made the site attractive to scholars interested in revealing biblical remains beneath the dust. The mound of Tell es-Sultan in the Jordan Valley has long been confidently equated with the biblical Jericho, and the wish to uncover the walls that collapsed at the blast of the Israelite trumpets has led to a series of excavations at the mound (fig. 1). The pioneer was C. Warren, who dug a few holes in 1873 but then abandoned the site and went on to excavate in Jerusalem. The Germans E. Sellin and C. Watzinger dug a series of trenches between 1907 and 1909, and they were followed by J. Garstang, 1930-36, and K. Kenyon, 1952-58.

While the town walls destroyed by Joshua's army have not been found, a series of Early Bronze- and Middle Bronze-Age walls and an impressive rampart have been uncovered and studied in detail. Beneath the biblical Jericho, first Garstang's and later the major excavations of Kenyon uncovered thick deposits of very early Pre-Pottery Neolithic occupation. A particularly surprising discovery made by Kenyon in the basal layers of this occupation was the existence of a massive stone perimeter wall. It is with the interpretation of this wall and the tower associated with it that this paper is concerned. The recent publication of the final archaeological reports, a project for which T. A. Holland is to be congratulated, makes it possible to reexamine Kenyon's conclusions using her own detailed observations (Kenyon 1981; Kenyon and Holland 1982, 1983).

The oldest remains at Jericho are dated to the Natufian culture, though not to its latest phase as recently defined (BarYosef 1981a, Valla 1984). Then, following a gap of nearly a millennium (ca. 9200-8350 B.c.), the site was settled by one of the early farming communities. The occupied area was a moderately sloping plain formed by the retreat of the Late Pleistocene Lisan Lake (fig. 1). The plain is covered by brown soils and gravels washed in by Wadi $\mathrm{Nu}^{\mathrm{c}}$ eima, Wadi el-Mafjar, and Wadi Qilt, forming the arable land of the Jericho oasis.

Table 1 summarizes the main construction and destruction events in the area of Trench I and squares FI, DI, and DII, where the walls, the tower, and adjacent buildings were partially exposed. Figure 2 tentatively reconstructs the main depo-

\footnotetext{
${ }^{1}$ (C) 1986 by The Wenner-Gren Foundation for Anthropological Research, all rights reserved 0011-3204/86/2702-0005 $\$ 1.00$. The reexamination of some of the archaeological problems of Jericho stemmed from research on Early Neolithic sites in the Lower Jordan Valley. Fieldwork was funded by the Wenner-Gren Foundation for Anthropological Research (1980-81) and by the National Geographic Society (1983-84), to whom I am very grateful for their support. I would like to thank P. Goldberg and A. Gopher of the Institute of Archaeology, Hebrew University, for many useful discussions in the field; Gl. Isaac and J. Merkel of the Peabody Museum, Harvard University, and Z. Herzog of the Institute of Archaeology, Tel Aviv University, for their helpful comments on an earlier draft; and B. Isaac for the drawings. I am, however, fully responsible for any shortcomings of the present version.
}

sitional events in this area; these sections are based on Kenyon's field drawings and written descriptions (Kenyon 1981). The available ${ }^{14} \mathrm{C}$ dates as reported by Burleigh $(1981,1983)$ are shown in both the table and the figure. The first Neolithic occupations were labelled "Proto-Neolithic" by Kenyon, but the lithic analysis of Crowfoot-Payne (1983) has demonstrated that the assemblage, mainly derived from a limited excavation in Square M, does not differ from the rest of the Pre-Pottery Neolithic A (henceforth PPNA) assemblages. This industry was renamed "Sultanian" and has since been found at two additional sites in the Jordan Valley-Gilgal (Noy, Schuldenrein, and Tchernov 1980) and Netiv Hagdud (Bar-Yosef, Gopher, and Goring-Morris 1980).

It is only subsequent to the earliest occupations that the freestanding wall and tower were built. The first perimeter wall, $3.6 \mathrm{~m}$ high, was $1.8 \mathrm{~m}$ thick at its base and only $1.1 \mathrm{~m}$ at its preserved top. The tower, placed inside the perimeter of the settlement, was $8.2 \mathrm{~m}$ high (ca. $9 \mathrm{~m}$ in diameter at the base and $7 \mathrm{~m}$ at the top) and built of undressed stones. It had a staircase leading to the top with 22 steps built of dressed slabs. Its preserved outlet seems to be the original one. No rooms were found inside the tower. The available ${ }^{14} \mathrm{C}$ dates indicate that the construction occurred between 8300 B.C. and 7800 B.C. which may mean around 8000 B.C. as estimated by Kenyon.

Stages IV-V consisted of the building of an additional wall (or only the thickening of the first wall) and the digging of a ditch in front of it, probably because the continuous rapid alluviation was endangering the existing structures. The tower was an extremely heavy structure (about 1,000 tons) and probably experienced differential subsidence of the underlying slippery marl. There is clear archaeological evidence that it had to be repaired at this stage.

The ditch was filled rapidly, motivating the addition of a third wall, and at the same period the staircase was blocked (Stages VI and VIA). Continuous accumulations on both sides consisting of natural aggradation enriched with occupational debris on the western face and occupational remains on the eastern face caused the walls to go out of use, leaving the tower still somewhat elevated above its surroundings. The ${ }^{14} \mathrm{C}$ readings point to a date of ca. $7400-7300$ B.C. In the final stage of the PPNA period the perimeter wall was entirely buried.

The lower courses of the PPNA perimeter wall were also found in the northern trench (Trench II) and were somewhat better preserved in the southern trench (Trench III). In these instances the wall was thinner, only $1.4 \mathrm{~m}$ and $1.6 \mathrm{~m}$ respectively. At the northern end of the settlement the perimeter wall was heavily damaged by a flooding wadi which left only the lower course of stones under a wadi channel some $15 \mathrm{~m}$ wide and about $1.5 \mathrm{~m}$ deep in its central thalweg. That the wadi was able to wash away a supposedly stone wall is somewhat unexpected, given the presence of soft occupation levels on either side; perhaps it was a mud-brick construction on stone foundations. In the southern trench the truncation of the already buried PPNA layers is interpreted as resulting from severe flooding in Wadi el-Mafjar.

Kenyon concluded that the oval mound of Jericho was encircled by a defensive wall enclosing an area of 2.4 hectares (originally miscalculated as 4.0). Her estimate of 3,000-4,000 for the site's population is too high in view of the size of the site, and the results of recent ethnoarchaeological research (Kramer 1982) point to an estimate of 400-900. Additional walls, also interpreted by Kenyon as "town walls," were uncovered in the western trench and dated to the following period, the Pre-Pottery Neolithic B (ca. 7300-6000 B.C.). These were slanting walls built of large undressed stones, retaining the earlier levels. Both the pictures of the walls and the drawing of the trench-section clearly show that, as has been pointed out by Mellaart (1975:59), these were retaining walls.

Kenyon's interpretations of her striking discoveries may be summarized as follows: 


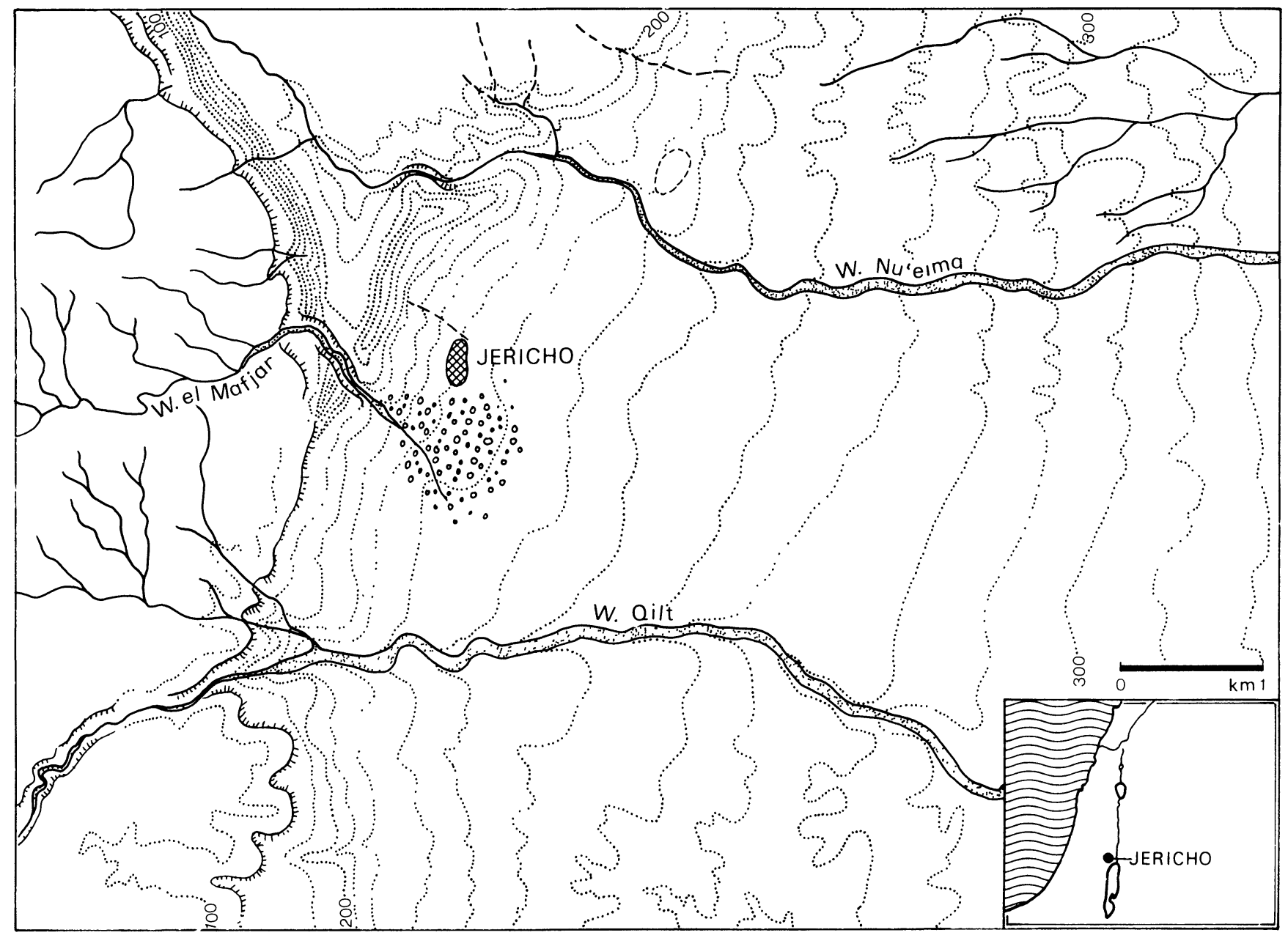

FIG. 1. The topographic situation of the tell of Jericho. Note the low ridge, immediately west of the tell, bordered by Wadi Nuceima in the north and Wadi el-Mafjar in the south. Topography is shown in 10-m contours. Today's spring rises on the mid-easter edge of the tell.

1. The presence of a thick, free-standing wall and a tower indicate a communal effort to fortify the settlement. (The effort required to build the perimeter wall was later calculated by Dorrell [1978] as about a week's worth for $200 \mathrm{men}$; a recalculation based on a more realistic estimate of $0.5 \mathrm{~m}^{3}$ per man per day yields a figure of 10,400 work days or about 104 work days for $100 \mathrm{men}$ ).

2. As a walled site, Jericho deserves to be called a "town" and is therefore comparable to the later Near Eastern fortified towns.

Both in the site reports and in her popular summary (Kenyon 1957), Kenyon avoided a certain number of intriguing questions:

1. Who were the enemies of Jericho that justified this communal effort, especially the investment in erecting the tower?

2. When the walls and the tower of the PPNA period went out of use because of the natural accumulation of house debris and refuse both inside and outside the settlement, why did the inhabitants not at once build new "town walls"?

3. Why was a terrace wall sufficient fortification during the PPNB period?

4. Why is there no record of other fortified sites in the Near East either at the time or thereafter up to about 5500 B.C.?

5. Why was the tower at Jericho built not on the outside of the wall, where its projection would enable the defenders to shoot attackers trying to climb it, but on the inside?

To reconsider Kenyon's interpretation we must explore the general evolution of prehistoric cultures in the Near East at that period and the specific location of Jericho and the geomorphic processes that may have influenced its history.

The evolution of prehistoric entities as represented in the archaeological record has recently been studied in depth in the various geographic units of the Near East (Sinai, the Negev, Edom, the Jordan Valley, the Damascus plateau, the El Kowm basin, and the Middle Euphrates Valley). On the basis of such features as site size, lithic and faunal assemblages, topographic locations, and zonal distribution, some general trends have been discerned (Cauvin 1978; Bar-Yosef 1981a, $b$; Henry 1983; Moore 1985). Without elaboration, these major developments may be summarized as a sequence of changes which took place from $11 / 12,000$ B.C. through 6000 B.C. mainly in the Mediterranean and Irano-Turanian vegetation zones, which shifted because of climatic fluctuations (Butzer 1978, Van Zeist, and Bottema 1982, Bintliff 1982).

The first change took place when small mobile groups of hunter-gatherers became partially or fully sedentary; long-term occupied sites accommodated larger bands (perhaps up to 5080 persons). This change is associated with the emergence of the Natufian culture, best recorded from the excavations of base camps such as Eynan (Ain Mallaha), Hayonim Cave and Terrace, El-Wad Cave and Terrace, and Nahal Oren Terrace (Perrot 1966, Valla 1984, Bar-Yosef and Goren 1973, Garrod and Bate 1937, Noy, Legge, and Higgs 1973). The Natufian economy was based on gathering (for which the evidence is rather scanty due to poor preservation in Mediterranean soils), hunting (mainly gazelle, fallow deer, roe deer, wild boar, ibex, 
TABLE 1

Sequence of Stages in the Western Sector of Jericho

\begin{tabular}{|c|c|c|c|c|c|}
\hline \multirow{3}{*}{$\frac{\text { STAGE }}{\text { I }}$} & \multicolumn{3}{|c|}{ STRUCTURE } & \multirow{2}{*}{\multicolumn{2}{|c|}{${ }^{14}$ C DATE B.C. }} \\
\hline & Walls & Tower & Other Structures & & \\
\hline & & $\begin{array}{l}\text { "Proto-Neolithic," no } \\
\text { structures }\end{array}$ & & (BM-106) & $8350 \pm 200$ \\
\hline II & & PPNA houses & & & \\
\hline III & "Town Wall" I & Tower & & $(\mathrm{BM}-105)$ & $8300 \pm 200$ \\
\hline IV & & & FI, DII enclosures & $\begin{array}{l}(\mathrm{P}-378) \\
(\mathrm{BM}-1327)\end{array}$ & $\begin{array}{l}7825 \pm 110 \\
7610 \pm 65\end{array}$ \\
\hline IVA & & & DI "silo" & (BM-1322) & $7430 \pm 85$ \\
\hline V & $\begin{array}{l}\text { "Town Wall" II added, } \\
\text { infilling chipped from } \\
\text { ditch in front of it }\end{array}$ & & & (BM-250) & $8350 \pm 500$ \\
\hline VI & $\begin{array}{l}\text { Ditch silted up } \\
\quad(\text { Pl. 236 JIII) }\end{array}$ & "Skin Wall" added & Enclosures destroyed & $(\mathrm{BM}-251)$ & $7440 \pm 150$ \\
\hline VIA & & $\begin{array}{l}\text { Staircase blocked, } 12 \\
\text { bodies inserted }\end{array}$ & $\begin{array}{l}\text { "Silo" burned; rounded } \\
\text { house built }\end{array}$ & $\begin{array}{l}(\mathrm{P}-379) \\
(\mathrm{BM}-1323)\end{array}$ & $\begin{array}{l}7705 \pm 84 \\
7430 \pm 85\end{array}$ \\
\hline VII & $\begin{array}{l}\text { "Town Wall" III added } \\
\text { on top of I and II }\end{array}$ & "Skin Wall" rebuilt & $\begin{array}{l}\text { Houses altered and rebuilt; } \\
\text { House AE built over } \\
\text { "Town Wall" III }\end{array}$ & & \\
\hline VIIA & "Town Walls" out of use & & & & \\
\hline VIIIA & & Top rebuilt (?) & Houses rebuilt; erosion begins & $\begin{array}{l}(B M-1787) \\
(B M-1321) \\
(B M-1326) \\
(B M-152)\end{array}$ & $\begin{array}{l}7330 \pm 100 \\
7280 \pm 80 \\
7280 \pm 220 \\
7330 \pm 150\end{array}$ \\
\hline VIIIB & & Tower out of use & Fire & & \\
\hline VIIIC & & & $\begin{array}{l}\text { Ceremonial structure } \\
\text { in FI }\end{array}$ & & \\
\hline IX & & $\begin{array}{l}\text { Fill almost reaches top } \\
\text { of tower }\end{array}$ & Domestic structures & $\begin{array}{l}(\mathrm{BM}-110) \\
(\mathrm{BM}-1789)\end{array}$ & $\begin{array}{l}8230 \pm 200 \\
7250 \pm 70\end{array}$ \\
\hline $\mathrm{X}$ & & $\begin{array}{l}\text { Contraction of site, } \\
\text { domestic structures }\end{array}$ & & & \\
\hline XI & & $\begin{array}{l}\text { Expansion, houses in } \\
\text { Trench I (west of } \\
\text { tower) } \\
\text { Erosional phase }\end{array}$ & & & \\
\hline
\end{tabular}

SourCES. Kenyon (1981), Kenyon and Holland (1982, 1983)

etc.), and fishing, mainly in inland lakes such as Hula Lake, on the shores of which the site of Eynan was established (BarYosef 1983).

Despite the expansion of the Natufian culture northward into the Middle Euphrates Valley and southward to the Negev, small groups of hunter-gatherers persisted in the desertic regions.

The establishment of farming communities cultivating both pulses and cereals (wheat and barley) took place during the PPNA period $\left({ }^{14} \mathrm{C}\right.$-dated ca. $8300-7300$ B.C.). Hunting was only partially replaced during the PPNB period (ca. 7300-6000 B.C.) by the introduction of domesticated sheep and goats (Clutton-Brock 1981, Davis 1982, Smith, Bar-Yosef, and Sillen 1984). Presumably these were herded from the Zagros (Iran) area, where the evidence for their domestication from local game is substantial, into the Levantine landscape (Hesse 1982). However, it is not impossible that goats, although only a very small fraction of the previously hunted Levantine fauna, were domesticated locally. The economy of the PPNB sites, situated in fertile areas such as the Euphrates Valley, the Damascus plain, the Trans-Jordanian plateau, and the Jordan and Jezreel Valleys, was based on legumes and cereal cultivation with some hunting and herding. In its final phase, at the end of the 7 th millennium B.C., cattle raising commenced.

During this period, climatic amelioration favoured the continued occupation of the deserts by hunter-gatherers. Their sites are found everywhere in the Negev, Sinai, and the SyroArabian desert. It is quite possible that the "desert kites," trapping devices for herd animals consisting of two long lowlying walls leading to an enclosure (often below a small cliff), were constructed in order to supply meat to the farmers of the
"Fertile Crescent." Many common features in art, ritual, mortuary practices, and the use of prestige goods, not detailed here, point to the presence of close contacts through gift giving, exchange, and "down-the-line" trade over most of the Near East and especially in the Levant (Renfrew and Dixon 1976, Mellaart 1975, Cauvin 1978, Moore 1985).

There is no archaeological evidence, in the form of burned settlements, the remains of mass massacres, or fortifications, for the existence of social aggression in the Levant before the 6th millennium B.C. This is not to say that there were no rivalries that ended in some fighting, but the archaeological record as shown in the deep stratigraphies of many tell sites (such as Mureybet, Abu Hureyra, Bouqras, Ramad, Asswad, Jericho, Ain Ghazal, and Netiv Hagdud) was mainly formed by the natural collapse and subsequent rebuilding of adobe or mud-brick houses. The noncontemporary erection of mud houses (sometimes on stone foundations) created what is known in archaeological jargon as "spiral stratigraphy"; new building layers are not recognizable over the entire area of a given tell, each excavation area having its own sequence of building events (Kramer 1983). On rare occasions general planning can be seen (as in the case of Tell Bouqras), but it is in no way interpretable as rebuilding after total destruction caused by warfare (Akkermans, Fokkens, and Waterbolk 1981).

Most Levantine Neolithic sites are partially and sometimes even completely buried in alluvial deposits. This is the case in the Jordan Valley, where sites like Beisamoun, Tell ${ }^{\mathrm{c}}$ Eli, Shacar HaGolan, Munhatta, and Netiv Hagdud have at least their basal layers beneath the surface level of the surrounding Holocene deposits and in many cases are entirely covered by these deposits (Lechevallier 1978, Prausnitz 1970, Stekelis 

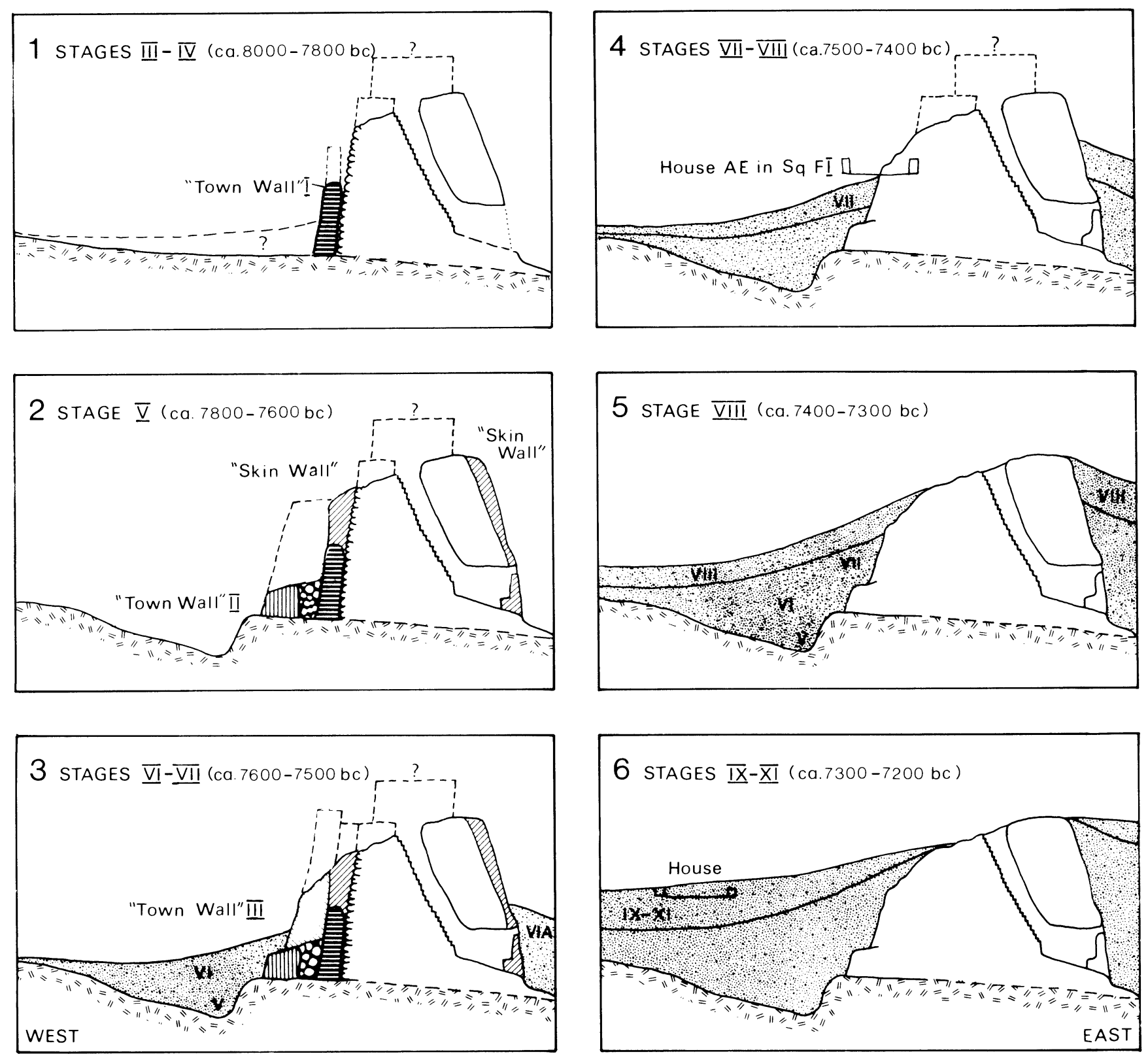

FIG. 2. Reconstructed sequence of depositional and building events as identified by K. Kenyon in Trench I. Major stages are indicated. The estimated dates are derived from the list of ${ }^{14} \mathrm{C}$ determinations given in table 1 . The broken line marks the suggested reconstructions of the walls and a shrine (?).

1972, Perrot 1964, Bar-Yosef, Gopher, and Goring-Morris 1980). Similar phenomena have been observed in the hilly areas, at Abu Ghosh and Yiftahel (Lechevallier 1978, Lamdan and Davis 1983), in the Negev, at Nahal Issaron (GoringMorris and Gopher 1983), and along the coastal plain, at Neve Yam (Wreschner 1977). The same situation has apparently been observed in other regions of the Near East. Indeed, even sites of later periods, when located in proximity to wadi courses, are partially or entirely buried. Such is the case with the Chalcolithic sites in Wadi Fazael (Jordan Valley), along Nahal Beer Sheva and Nahal Besor (northern Negev), and on the coastal plain (e.g., Olesh). The Early Bronze I site of ${ }^{\mathrm{C}} \mathrm{En}$ Shadud (Jezreel Valley) indicates that even sites as late as around 3000 B.C. may have been buried (Braun and Gibson 1984). The section drawing from Trench I in Jericho clearly shows that Kenyon observed this phenomenon. Alluvial deposits filled the ditch dug by the Neolithic inhabitants. Stream flow removed the PPNA wall on the northern edge of the tell and levelled the top of the PPNA deposits in Trench III.
The situation of Neolithic sites, especially the early ones, near watercourses and in low-lying areas possibly reflects the desire of their inhabitants to have drinking and washing water immediately available and to live close to fields that made use of readily cultivated soils on alluvial fans and terraces. In some cases the potential for simple irrigation may have been an added incentive. Despite the limited number of palynological records from lakes (Van Zeist and Bottema 1982) and their partial disagreement, it seems that both PPNA and PPNB periods had more favourable climatic conditions than today. Average annual temperatures were somewhat lower, the sea was continually rising, achieving its maximum height only a millennium later, and the distribution of annual precipitation resulted in better spread of Mediterranean forests and richer Irano-Turanian steppes. Geomorphological evidence supports this general picture and indicates that the 7 th millennium B.C. was wetter than the previous or following ones, permitting the existence of inland lakes in Syria, Trans-Jordan, Arabia, the Jordan Valley, and other intermontane valleys. The aggrada- 
tional deposits in alluvial fans show few large boulders such as those carried by severe floods in historical and present times. It seems that the annual flooding of terraces and alluvial fans provided a new veneer of soil which in the absence of organic fertilizers made possible almost continuous cultivation. This kind of annual or semiannual sheetwash and mudflow, however, required some kind of protection for settlements located amongst the fields. A defense system providing protection from natural activities can be a simple one-a water-diverting trench-or a more sophisticated one, given the situation and the capabilities of the inhabitants.

The tell of Jericho is, as I have said, located on what used to be a moderately sloping plain which formed the residual landscape of a receding lake. The marls which form the bedrock at Jericho accumulated in this lake, which regressed from this area ca. 11,000 B.C. On the west side, the Jericho sector of the slope is protected by a low ridge, ca. $2 \mathrm{~km}$ long, which more or less encircles the area (fig. 1). Two wadis border this ridge, Wadi $\mathrm{Nu}^{\mathrm{c} e i m a}$ at the northern end and Wadi el-Mafjar at the southern. Wadi el-Mafjar descends from the Judean Hills and has a small drainage basin (ca. $20 \mathrm{~km}^{2}$ ); the apex of its former alluvial fan is only about $500 \mathrm{~m}$ from the tell. That the wadis of the region once carried more water than they do today seems obvious from the erosion reported by Kenyon on the northern edge of the mound. Heavy sediment discharge from the wadis would be expected with an increase in direct precipitation on the Judean Hills but perhaps also would have come as a result of vegetational destruction caused by the local inhabitants. The cutting of wood (e.g., poplar, tamarisk, willow, oak, fig) and bushes is evident not only in the large amounts of charcoal in the archaeological deposits but also in the use-wear visible on the cutting edges of the axes-adzes (Western 1983, Keeley 1983). To what extent fire became a tool for land clearing is unknown, although botanical studies following fires in Mediterranean maquis have shown that it has none of the advantages there that it has in tropical or temperate zones.

Given all the available data, it seems that a plausible alternative interpretation for the Neolithic walls of Jericho is that they were built in stages as a defense system against floods and mudflows. The PPNA inhabitants of Jericho chose to live near a copious spring on a sloping plain which was subject to mudflows and sheetwash. Their response was to build a wall and then, when necessary, dig a ditch. The necessity for better protection on the western side would explain the varying thickness of the wall, which during Stages IV-VI was ca. $3.5 \mathrm{~m}$ in the west but remained only $1.4-1.6 \mathrm{~m}$ in the north and the south. The dangers of erosion are evident in the destruction of the wall on the northern edge of Jericho at the end of the PPNA or before. Later, in PPNB days, the tell was presumably high enough to stand above the floods, and such protection as may have been necessary was provided by a simple terrace revetment. Moreover, this terrace wall could have been just a structural device to provide sound foundations for houses on the top level above it and at its base.

Testing of this alternative explanation at Jericho and other sites is needed. One may predict (1) that the PPNA wall at Jericho only partially protected the early occupations, (2) its height and thickness vary in response to uneven alluviation or flowing water, and (3) similar devices will be uncovered at other sites of the period.

Kenyon failed to find a continuation of the wall on the western edge, where she opened an additional excavation (Site $\mathbf{M}$ ). The eastern end of the mound is partially destroyed and covered by the main north-south Jordan Valley road. (A rough estimate indicates that the eastern wall, if there was one on that side, would be about 4-7 m below Area H.)

One other excavated Neolithic site at which the edge of the site has been exposed is Beidha, located northwest of Petra (Jordan) and situated in a wide wadi, deeply entrenched in Nubian sandstone (Kirkbride 1968). There the excavator ex- posed a terrace wall, $2 \mathrm{~m}$ high and at least $50 \mathrm{~m}$ long, which protected the wadi terrace on which the site was built from the flowing water. Kirkbride never claimed that this wall was part of a defensive system, because in her first sounding she found a staircase built on its outer face. She interpreted the wall as a support for the sandy terrace on which this PPNB site was built, but in reality it could have been a protection against constant denudation by water undercutting the terrace. Finally, either in PPNB times or later the entire wadi was filled up and the terrace wall buried in a sandy-gravel deposit.

Undoubtedly more testing is needed at other sites, and good candidates for such an operation will be those located in the Jordan Valley. For example, the PPNA mound of Netiv Hagdud is situated $350 \mathrm{~m}$ from the apex of an alluvial fan, just where the wadi comes out onto the plain (Bar-Yosef, Gopher, and Goring-Morris 1980). This shallow tell (ca. $4 \mathrm{~m}$ high) was totally covered on its western side by sand and gravel accumulations. The results of past water activity are visible, and the question is, Did the inhabitants of Netiv Hagdud need to do something about it? Only further excavations will enable us to resolve this question.

Until now an alternative interpretation for the tower has not been discussed. The later history of Near Eastern fortifications seems to rule out its use as part of a fortress. Perhaps the most intriguing thing about it is its fine state of preservation.

In view of the erosional phase which occupied the time gap between the PPNA period and the onset of the PPNB period, it is surprising that such a building remained almost intact. Moreover, while the height of PPNA deposits in other parts of the mound is $3.5-4.5 \mathrm{~m}$, in the area of the tower the total thickness amounts to $8.5 \mathrm{~m}$ (including the so-called ProtoNeolithic). The special mud-brick structures uncovered by Kenyon on the northern side of the tower have been described as "water tanks" which later served as silos (Kenyon 1981) or "tanning vats" (Marshall 1982). The construction of water reservoirs only $80 \mathrm{~m}$ from a bountiful spring seems highly unlikely and indicates that Kenyon's interpretation was based on her view that Jericho was a fortified town which, like those of the Iron Age, needed water supplies inside the walls. The location of the spring on the eastern edge of the mound points to the possibility of its being included within the perimeter wall circumference, if this wall did indeed encircle the entire site.

The archaeological remains indicate that the tower was a special structure and perhaps held a special place within the settlement. A preliminary composite north-south cross-section of the tell, based on the available drawn sections (Kenyon 1981), indicates that the tower created a bump in the general topographic configuration of the tell, and I would venture to predict that there was only one tower in the Pre-Pottery Neolithic A of Jericho. The preservation of its top would be explained if one postulated that it had been capped by a mudbrick superstructure (fig. 2). The presence of the storage facilities attached to it in its early days may hint that it was publicly owned or at the service of the community. It is quite possible that it was also a place or a center for ritual activities. Some evidence in support of this suggestion is given by Kenyon's finds in Square FI (immediately north of the tower) in the form of peculiar structures which suggested "a ceremonial significance" (Kenyon 1981:50). Finally, it should be mentioned that the tower is close to the spring. Unfortunately, Kenyon did not have time or funds to finish her excavation at Site $\mathrm{H}$ (only $50 \mathrm{~m}$ from the tower), which was aimed at reaching the prehistoric outlet of the spring.

The climatic optimum of the early Holocene made possible the emergence and growth of farming communities in the Near East. Agriculture as a new subsistence strategy succeeded because the environmental conditions were appropriate while new social structures were in the process of being formed. It was only later, during the 6th millennium B.C., that climatic fluctuations, demographic pressures, the development of pas- 
toral societies, and the collapse of simple social organizations in parts of the Near East caused the group aggression that was met by new means of defense in the form of fortification systems. It seems that the Pre-Pottery Neolithic A walls of Jericho were built in a period when the people had other things in mind, namely, protecting their settlement from the vagaries of nature.

\section{References Cited}

Akkermans, P. A., H. Fokkens, and H. T. Waterbolk. 1981. "Stratigraphy, architecture, and layout of Bouqras," in Préhistoire $d u$ Levant. Edited by J. Cauvin and P. Sanlaville, pp. 485-502. Paris: CNRS.

BAR-YoSEF, O. 1981a. "Epi-Palaeolithic complexes in the southern Levant," in Préhistoire du Levant. Edited by J. Cauvin and P. Sanlaville, pp. 389-408. Paris: CNRS

. 1981b. "The 'Pre-Pottery Neolithic' period in the southern Levant," in Préhistoire du Levant. Edited by J. Cauvin and P. Sanlaville, pp. 555-69. Paris: CNRS.

. 1983. "The Natufian in the southern Levant," in The hilly flanks: Essays on the prehistory of Southwestern Asia. Edited by T. C. Young, P. E. L. Smith, and P. Mortensen, pp. 11-42. Oriental Institute of the University of Chicago Studies in Ancient Oriental Civilizations 36

BAR-Yosef, O., and N. GoREN. 1973. Natufian remains in Hayonim Cave. Paléorient 1:49-68.

Bar-Yosef, O., A. Gopher, and A. N. Goring-Morris. 1980. Netiv Hagdud: A Sultanian mound in the Lower Jordan Valley. Paléorient 6:201-6.

BintLifF, J. 1982. "Palaeoclimatic modelling of environmental changes in the East Mediterranean region since the last glaciation," in Palaeoclimates, palaeoenvironments, and human communities in the eastern Mediterranean region in later prehistory, pt. 2. Edited by J. L. Bintliff and W. Van Zeist, pp. 485-527 British Archaeological Reports International Series 133.

Braun, E., and S. Gibson. 1984. 'En Shadud: An Early Bronze I farming community in the Jezreel Valley. Bulletin of the American Schools of Oriental Research 253:41-54.

BURLEIGH, R. 1981. "Radiocarbon dates," in Excavations at Jericho, vol. 3. Edited by T. A. Holland, pp. 501-4. London: British School of Archaeology in Jerusalem.

. 1983. "Additional radiocarbon dates for Jericho," in Excavations at Jericho, vol. 5. Edited by K. M. Kenyon and T. A. Holland, pp. 760-65. London: British School of Archaeology in Jerusalem.

BUTZER, K. W. 1978. "The late prehistoric environmental history of the Near East," in Environmental history of the Near East and Middle East since the last glacial age. Edited by W. C. Brice, pp. 512. London: Academic Press.

Cauvin, J. 1978. Les premiers villages de Syrie-Palestine de IXeme au VII eme millenaire avant J.C. Lyon: Maison de l'Orient.

Clutton-Brock, J. 1981. Domesticated animals from early times. Austin: University of Texas Press.

Crowfoot-Payne, J. 1983. "The flint industries of Jericho," in Excavations at Jericho, vol. 5. Edited by K. M. Kenyon and T. A Holland, pp. 622-759. London: British School of Archaeology in Jerusalem.

DAvIS, S. 1982. Climate change and the advent of domestication: The succession of artiodactyls in the Late Pleistocene-Holocene period in the Israel region. Paléorient 8:5-14.

DORRELl, P. 1978. "The uniqueness of Jericho," in Archaeology in the Levant: Essays for Kathleen Kenyon. Edited by R. Moorey and P. Parr, pp. 11-18. Warminster: Aris and Phillips.

Garrod, D. A. E., and D. M. A. BATE. 1937. The Stone Age of Mount Carmel. Oxford: Clarendon.

Goring-Morris, A. N., and A. Gopher. 1983. Nahal Issaron: A Neolithic settlement in the southern Negev. Israel Exploration Journal 33:149-62.

HENRY, D. O. 1983. "Adaptive evolution within the Epipalaeolithic of the Near East," in Advances in world archaeology, vol. 2. Edited by F. Wendorf and A. E. Close, pp. 99-160. New York: Academic Press.

HESSE, B. 1982. Slaughter patterns and domestication: The beginnings of pastoralism in western Iran. Man 17:403-17.
Keeley, L. H. 1983. "Microscopic examination of adzes," in Excavations at Jericho, vol 5. Edited by K. M. Kenyon and T. A. Holland, p. 759. London: British School of Archaeology in Jerusalem.

Kenyon, K. 1957. Digging up Jericho. London: Benn. 1981. Excavations at Jericho. Vol 3. The architecture and stratigraphy of the tell. Edited by T. A. Holland. London: British School of Archaeology in Jerusalem.

Kenyon, K., and T. A. Holland. Editors. 1982. Excavations at Jericho. Vol. 4. The pottery-type series and other finds. London British School of Archaeology in Jerusalem.

- Editors. 1983. Excavations at Jericho. Vol. 5. The pottery phases of the tell and other finds. London: British School of Archaeology in Jerusalem.

KirkBRIDE, D. 1968. Beidha 1967: An interim report. Palestine Exploration Quarterly 100:90-96.

KRAMER, C. 1982. Village ethnoarchaeology. New York: Academic Press.

- 1983. "Spatial organization in contemporary Southwest Asian villages," in The hilly flanks. Edited by T C. Young, P. E. L. Smith, and P. Mortensen, pp. 347-68. Oriental Institute of the University of Chicago Studies in Ancient Oriental Civilizations 36 .

Lamdan, M., and M. Davis. 1983. Le site de Yiftah'el (Israel). L'Anthropologie 87:275-76

Lechevallier, M. 1978. Abou Ghosh et Beisamoun: Deux gisements du VIIe millenaire avant l'ère chrétienne en Israel. (Mémoires et Travaux du Centre de Recherches Préhistoriques Français de Jérusalem 2.) Paris: Association Paléorient.

MARShALL, D. N. 1982. "Jericho bone tools and objects," in Excavations at Jericho, vol. 4. Edited by K. M Kenyon and T. A. Holland, pp. 570-622. London: British School of Archaeology in Jerusalem.

MellaART, J. 1975. The Neolithic of the Near East. London· Thames and Hudson.

MooRe, A. 1985. "The development in Neolithic societies in the Near East," in Advances in world archaeology, vol. 5. Edited by $\mathrm{F}$ Wendorf and A. E Close. New York: Academic Press. In press.

Noy, T., A. J. LegGe, and E. S. Higgs. 1973. Recent excavations at Nahal Oren, Israel. Proceedings of the Prehistoric Society 39:7599.

Noy, T., J. Schuldenrein, and E. Tchernov. 1980. Gilgal: A PrePottery Neolithic A site in the Lower Jordan Valley. Israel Explora tion Journal 30:63-82.

PERROT, J. 1964. Les deux premières campagnes de fouille à Munhatta. Syria $41 \cdot 328-45$

. 1966. Le gisement Natoufien de Mallaha (Eynan) Israèl. L'Anthropologie 70:437-84.

Prausnitz, M. W. 1970. From hunter to farmer and trader. Jerusalem: Sivan Press.

RENFrew, C., and J. Dixon. 1976. "Obsidian in Western Asia. A review," in Problems in economic and social archaeology. Edited by G. de G. Sieveking, I. H. Longworth, and K. E. Wilson, pp. 13750. London: Duckworth.

Smith, P., O. Bar-Yosef, and A. Sillen. 1984. "Archaeological and skeletal evidence for dietary change during the late Pleistocene/ Early Holocene in the Levant," in Paleopathology at the origins of agriculture. Edited by M. N. Cohen and G. J. Armelagos, pp. 10136 New York: Academic Press.

Stekelis, M. 1972. The Yarmukian culture. Jerusalem: Magness Press, Hebrew University.

VALla, F. R. 1984 Les industries de silex de Mallaha (Eynan) et du Natufien dans le Levant. (Mémoires et Travaux du Centre de Recherches Préhistoriques Français de Jérusalem 5.) Paris: Association Paléorient.

VAN ZEIST, W., and S. BotTema. 1982. "Vegetational history of the eastern Mediterranean and the Near East during the last 20,000 years," in Palaeoclimates, palaeoenvironments, and human communities in the eastern Mediterranean region in later prehistory, pt. 2. Edited by J. L. Bintliff and W. Van Zeist, pp. 277-321. British Archaeological Reports International Series 133.

Western, A. C. 1983. "Catalogue of identified charcoal samples," in Excavations at Jericho, vol. 5. Edited by K. M. Kenyon and T. A. Holland, pp. 770-73. London: British School of Archaeology in Jerusalem

WRESCHNER, E. E. 1977. Neve Yam: A submerged Late Neolithic settlement near Mt. Carmel. Eretz Israel 13:259-70. 